\title{
Estradiol Priming Potentiates the Kisspeptin-Induced Release of LH in Ovariectomized Cows
}

\author{
Gustavo Guerino Macedo 1,*(D), Emiliana de Oliveira Santana Batista ${ }^{2}$, Gustavo Martins Gomes dos Santos ${ }^{3}$, \\ Michael J. D’Occhio ${ }^{4}\left(\mathbb{D}\right.$ and Pietro Sampaio Baruselli ${ }^{2, *}$ (i)
}

1 Faculty of Veterinary Medicine and Animal Sciences, Federal University of Mato Grosso do Sul, Campo Grande 79070-900, Mato Grosso do Sul, Brazil

2 Faculty of Veterinary Medicine and Animal Science, University of Sao Paulo, Sao Paulo 05508-270, Sao Paulo, Brazil; emilianamili@hotmail.com

3 Sheepembryo, Londrina 80010-000, Parana, Brazil; gugamgs@hotmail.com

4 Faculty of Science, School of Life and Environmental Sciences, The University of Sydney, Sydney, NSW 2006, Australia; michael.docchio@sydney.edu.au

* Correspondence: gustavo.macedo@ufms.br (G.G.M.); barusell@usp.br (P.S.B.); Tel.: +55-67-3345-3600 (G.G.M.); +55-11-3091-7674 (P.S.B.)

check for updates

Citation: Macedo, G.G.; Batista, E.d.O.S.; Santos, G.M.G.d.; D'Occhio, M.J.; Baruselli, P.S. Estradiol Priming Potentiates the Kisspeptin-Induced Release of LH in Ovariectomized Cows. Animals 2021, 11, 1236. https://doi.org/10.3390/ani11051236

Academic Editor: Jim McFarlane

Received: 26 February 2021

Accepted: 22 April 2021

Published: 25 April 2021

Publisher's Note: MDPI stays neutral with regard to jurisdictional claims in published maps and institutional affiliations.

Copyright: (c) 2021 by the authors. Licensee MDPI, Basel, Switzerland. This article is an open access article distributed under the terms and conditions of the Creative Commons Attribution (CC BY) license (https:// creativecommons.org/licenses/by/ $4.0 /)$.
Simple Summary: The magnitude and duration of the pre-ovulatory release of LH is important in controlling the timing of ovulation in estrus synchronization and fixed-time artificial insemination (FTAI) protocols in cows. The neuropeptide kisspeptin (KISS1) stimulates GnRH neurons in the brain which in turn induce LH release from the pituitary gland. The present study used ovariectomized Nelore cows as a model to examine whether priming with the steroid estradiol benzoate (EB) for $12 \mathrm{~h}$ increased both the peak and duration of LH release after treatment with KISS1. It was found that cows pre-treated with EB for $12 \mathrm{~h}$ showed a greater LH peak and longer duration of LH release in response to KISS1 compared with cows that received EB at the same time as KISS1, or KISS1 alone. The incorporation of EB priming and KISS1 in estrus synchronization-FTAI protocols could improve the control of LH release and ovulation, and potentially increase fertilization and conception rates in cows. This would have important practical application in assisted breeding in beef and dairy cows.

Abstract: The present study examined whether priming with estradiol benzoate (EB) for $12 \mathrm{~h}$ increased both the peak and duration of LH release in response to kisspeptin (KISS1, KP) in cows. In a Latin square design, ovariectomized Nelore cows $(n=8)$ received: Control, i.m. $4 \mathrm{~mL}$ of $0.9 \%$ saline; KP, i.m. 4 mg murine KISS1-10; EBKP, i.m. 4 mg KISS1-10 + i.m. 2 mg EB simultaneously; EB12KP, i.m. $4 \mathrm{mg}$ KISS1-10 + i.m. 2 mg EB $12 \mathrm{~h}$ before KISS1-10. Concentrations of LH were determined in blood samples obtained at time 0 (treatment), 20, 40, 60, 90, 120, 150, 180, 210 and $270 \mathrm{~min}$. Concentrations of LH were analyzed by Proc GLIMMIX for repeated measures. In case of significance, the adjusted Tukey test was used to test for differences among treatments. GraphPad 8.0 PRISM ${ }^{\circledR}$ was used to determine the area under the LH-response curve (AUC) after injection of KISS1-10. Plasma LH remained relatively constant throughout sampling after treatment with saline. The peak in LH after injection of KISS1-10 occurred at $20 \mathrm{~min}$ in Groups KP and EBKP and at $40 \mathrm{~min}$ in Group EB12KP. The peak $\mathrm{LH}$ response $(\Delta \mathrm{LH}, \mathrm{ng} / \mathrm{mL})$ was greater $(p<0.01)$ in Group EB12KP $(5.6 \pm 0.9)$ than in Groups KP (2.4 \pm 0.9$)$ and EBKP (3.5 \pm 0.9$)$, which did not differ. AUC (LH ng/mL*min) was greater $(p=0.02)$ in Group EB12KP (439 \pm 73$)$ than in Groups KP (176 \pm 73$)$ and EBKP $(241 \pm 73)$, with the latter two groups not differing. The findings indicated that $12 \mathrm{~h}$ priming with EB increased both the peak and duration of the LH response to treatment with KISS1. The incorporation of EB priming and KISS1 could improve the efficiency of estrus synchronization with fixed-time AI in cows. This would have an important practical application in assisted breeding in beef and dairy cattle.

Keywords: estradiol priming; kisspeptin; LH; fixed-time AI; cow 


\section{Introduction}

Synchronization of the stage of the estrous cycle and ovulation, combined with fixedtime artificial insemination (FTAI), has proven to be a powerful technology platform to improve both reproductive performance and the rate of genetic gain in beef and dairy cattle [1]. The adoption of assisted reproductive technology has increased rapidly as the beef and dairy industries have sought to develop efficient and sustainable production systems to meet the growing demand for animal protein [2]. The large-scale adoption of assisted breeding requires that the technology has a high level of success and is optimally cost-effective [3]. Even modest gains in the efficiency of assisted breeding can have major impact when applied across the beef and dairy industries.

The synchronization of ovulation in preparation for FTAI remains an area where further improvements can be made. Critical to the control of ovulation are the magnitude and timing of the pre-ovulatory surge release of LH [4]. Hormones that are most commonly used to influence the timing of the LH surge include GnRH [5] and estradiol (E2) [6]. Other hormones that directly influence the maturation and ovulation of ovarian follicles are human chorionic gonadotropin (hCG) [7] and equine chorionic gonadotropin (eCG) [8]. All of these hormones are used singularly and in different combinations, as summarized in several reviews [9-12]. More recently, kisspeptin (KISS1) has been added to hormones that can be used to stimulate the release of LH in cattle [13].

An outstanding issue in synchronization-FTAI protocols is whether greater precision can be achieved in both the timing and magnitude of LH release. An improvement in the control of LH release should reduce the variability in the interval from treatment to ovulation [14]. This would increase the likelihood of fertilization at FTAI. A combination of KISS1 and E2 provides two potential mechanisms for the control of LH release from gonadotrope cells in the anterior pituitary gland. In this approach, E2 would have a priming effect on gonadotrope cells which should enhance their sensitivity and response to GnRH. KISS1 could stimulate the release of LH through two pathways. One pathway is the established action of KISS1 at GnRH neurons in the hypothalamus [15]. A second potential pathway could be a direct action of KISS1 on gonadotrope cells [16]. Gonadotropes have KISS1 receptor GPR54 [17] and KISS1 induced LH release from cultured bovine anterior pituitary cells [18]. However, KISS1 receptor GRP54 also occurs on pituitary lactotrope and somatotrope cells and it remains unclear whether KISS1 action at the gonadotrope cells is an important component of LH release [19]. Notwithstanding, the above KISS1 + E2 rationale was used in the present study to examine LH release in OVX cows treated with KISS1, either alone or in combination with E2. OVX cows were used in the present study to exclude the endogenous source of ovarian steroids. Ovarian E2 and P4 have a feedback action in the brain which regulates the release of GnRH and LH in cows [20]. It was important to use a model in the present study which excluded a potential effect of endogenous E2 and P4 on the response to KISS1. The hypothesis tested was that pre-exposure to E2 would have a priming effect and increase the LH response to KISS1 in cows. This information could provide new insight on the mechanisms that control LH release in cattle with potential application in estrus synchronization-FTAI protocols in beef and dairy cows.

\section{Materials and Methods}

\subsection{Animals and Experimental Procedures}

The study had approval from the Ethics Committee of the University of Sao Paulo, Sao Paulo, Brazil (protocol \#2537/2012). Nelore (Bos indicus) cows ( $n=8 ; 3$-y-old; $432 \pm 27 \mathrm{~kg}$ ) were used. They were maintained on pasture that was predominant in palisade grasses (Brachiaria brizanta) and had free access to mineralized salt and water. All cows underwent bilateral ovariectomy (OVX) using an established L-block flank laparotomy technique [21]. Briefly, the flank was incised using aseptic conditions and the subcutaneous and muscular layers were separated to gain access to the peritoneal cavity. After removal of both ovaries, the peritoneum, muscle layer, and skin, were sutured separately. Cows were monitored for $24 \mathrm{~h}$ after surgery and the wounds checked at 3 and 7 days. 
One month after ovariectomy, the eight cows were used in a Latin square experimental design. The treatments were as follows: (1) Control, cows received i.m. $4 \mathrm{~mL} 0.9 \%$ saline; (2) KP, cows received i.m. $4 \mathrm{mg}$ murine KISS1-10 in $4 \mathrm{~mL} \mathrm{0.9 \%} \mathrm{saline;} \mathrm{(3)} \mathrm{KP} \mathrm{+} \mathrm{estradiol}$ benzoate (EBKP), cows received i.m. 4 mg KISS1-10 + i.m. 2 mg EB (Sincrodiol ${ }^{\circledR}$, Ourofino, Brazil) simultaneously; (4) EB12KP, cows received i.m. $2 \mathrm{mg}$ EB $12 \mathrm{~h}$ before i.m. $4 \mathrm{mg}$ KISS110 (Figure 1). At days $0,10,20$ and 30, two cows were randomly assigned to each treatment so that at the end of the experiment all cows had received all treatments $(n=8 /$ treatment), and no cow received a single treatment twice. The dose of KISS1-10 was intended to give approximately $10 \mu \mathrm{g}$ KISS1-10/kg BW based on a previous report [13]. The EB dose was also based on previous studies [6]. Murine KISS1-10 decapeptide was obtained by custom synthesis (American Peptides Company, Inc., Sunnyvale, CA, USA). The KISS1-10 peptide was $96.5 \%$ pure based on HPLC analysis and was of molecular mass unit 1318.4 based on mass spectral analysis.

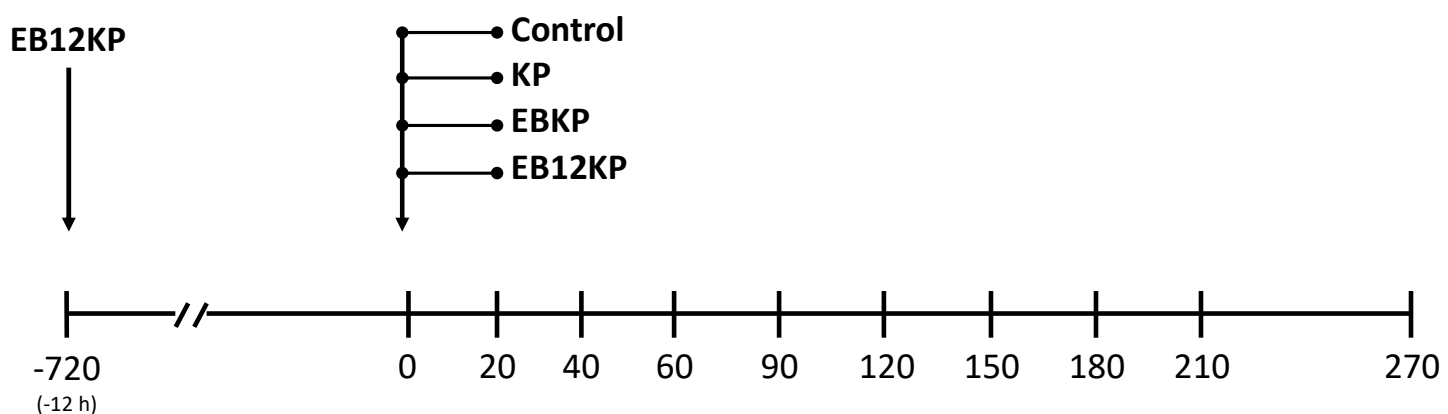

Time ( $\mathrm{min})$ for blood samples

Figure 1. Study design. Ovariectomized Nelore cows $(n=8)$ were used in a Latin square design and received the following treatments: Control, i.m. 4 mL 0.9\% saline; KP, i.m. 4 mg murine KISS1-10 in 4 mL 0.9\% saline; EBKP, i.m. 4 mg KISS1-10 + i.m. 2 mg estradiol benzoate (EB) simultaneously; EB12KP, i.m. 2 mg EB 12 h before i.m. 4 mg KISS1-10. Blood samples were obtained at $0,20,40,60,90,120,150,180,210$, and 270 min relative to the time of treatment.

Blood samples $(8 \mathrm{~mL})$ were obtained by jugular venipuncture to determine circulating concentrations of LH. Samples were taken at 0, 20,40,60, 90, 120, 150, 180, 210, and $270 \mathrm{~min}$ relative to the time of treatment (Figure 1). A sampling interval of $20-30 \mathrm{~min}$ was chosen based on the established nature of pituitary LH release in cattle which is characterized by random pulses and a half-life in circulation of 20-30 min. Blood was collected into evacuated tubes containing sodium heparin (Vacutainer ${ }^{\circledR} ;$ Becton-Dickinson \& Company, Franklin Lakes, NJ, USA) and placed on ice until centrifugation $(1500 \times g$ for $20 \mathrm{~min}, 4^{\circ} \mathrm{C}$ ). Plasma was stored at $-20^{\circ} \mathrm{C}$ until processed for $\mathrm{LH}$ and progesterone (P4) radioimmunoassay (RIA).

\subsection{Hormone Quantification}

Concentrations of $\mathrm{P} 4$ in circulation were measured to confirm that the OVX had removed ovarian tissue and that there was no endogenous source of $\mathrm{P} 4$ in the cows. Endogenous P4 would influence the responses to treatment with E2 and KISS1. The P4 radioimmunoassay used a commercial kit (Coat-A-Count, Diagnostics Products Co., Los Angeles, CA, USA) with sensitivity of $0.05 \mathrm{ng} / \mathrm{mL}$. Samples were analyzed for P4 in the one assay and the intra-assay coefficient of variation was $4.3 \%$. LH was quantified by a liquid phase double antibody radioimmunoassay as described previously [22]. Highly purified LH (AFP8614B; National Hormone and Pituitary Program, Rockville, MD, USA) was used to prepare both the radioiodinated LH and reference LH standards. The sensitivity of the assay was $0.05 \mathrm{ng} / \mathrm{mL}$. The intra- and inter-assay coefficients of variation were $10.3 \%$ and $13.1 \%$, respectively. 


\subsection{Statistical Analyses}

The program GraphPad 8.0 PRISM ${ }^{\circledR}$ (https:/ /www.graphpad.com/guides/prism/8/ user-guide/index.html, accessed on 25 April 2021) was used to identify pulses of LH and to determine the following LH secretory characteristics: basal concentration; area under the LH-response curve (AUC, LH released from the beginning until the end of the LH peak after injection of KISS1-10); and $\triangle \mathrm{LH}$ (peak LH concentration after injection of KISS1-10 minus the concentration at $0 \mathrm{~min}$ ). Statistical analysis was performed with the Statistical Analysis System software for IOS (SAS ${ }^{\circledR}$ University Edition; https: / /www.sas.com/en_au/ software/university-edition/download-software.html, accessed on 24 November 2020). Variables were assessed with the UNIVARIATE procedure for normality of residuals by the Shapiro-Wilk test, and for homogeneity of variances with the Bartlett test. AUC and $\Delta \mathrm{LH}$ did not show normality of residuals and the data were transformed to Log-10 before analysis. Concentrations of LH were analyzed by Proc GLIMMIX for repeated measures. Concentrations of P4 at time 0 were analyzed by Proc GLIMMIX. In case of significance, the adjusted Tukey test was used to test for differences among treatments. A 5\% significance level was used, and the data are presented as estimated means \pm SEM.

\section{Results}

\subsection{Progesterone}

Concentrations of $\mathrm{P} 4$ in circulation were low $(0.43 \pm 0.08 \mathrm{ng} / \mathrm{mL}$, treatments combined $)$ as would be predicted for OVX cows that lack ovaries to secrete P4. There was no difference $(p=0.87)$ in $\mathrm{P} 4$ among treatment groups.

\section{2. $\mathrm{LH}$}

Concentrations of LH in circulation before treatment with KISS1-10 (time $0 \mathrm{~min}$ ) did not differ $(p=0.89)$ among the treatment groups (Control, $1.45 \pm 0.65 ; \mathrm{KP}, 1.34 \pm 0.65$; $\mathrm{EBKP}, 2.02 \pm 0.65 ; \mathrm{EB} 12 \mathrm{KP}, 1.39 \pm 0.65 \mathrm{ng} / \mathrm{mL}$ ). $\mathrm{LH}$ remained relatively constant from 0 to $270 \mathrm{~min}$ when cows received $0.9 \%$ saline and served as controls (Figure 2).

Treatment with KISS1-10 consistently induced a release of LH $(p=0.0135)$. The highest concentration of LH occurred at $20 \mathrm{~min}$ in Groups KP and EBKP (Figure 2). Group EB12KP had the highest concentration of LH at $40 \mathrm{~min}$. The amplitude of the $\mathrm{LH}$ response $(\Delta \mathrm{LH})$ was similar for Groups KP and EBKP, which both had a lesser $(p<0.01)$ LH amplitude response than Group EB12KP (Table 1).

Table 1. Parameters of LH release in ovariectomized Nelore cows treated i.m. with 4 mg murine KISS1-10 (KP); KISS1-10 + i.m. 2 mg estradiol benzoate simultaneously (EBKP); and KISS1-10 + i.m. $2 \mathrm{mg}$ EB $12 \mathrm{~h}$ before KISS1-10 (EB12KP). AUC (LH ng/mL*min), area under the LH-response curve; $\triangle \mathrm{LH}(\mathrm{ng} / \mathrm{mL})$, highest $\mathrm{LH}$ concentration minus the $\mathrm{LH}$ concentration at time 0 min (treatment). Results are means \pm sem.

\begin{tabular}{ccccc}
\hline & KP & EBKP & EB12KP & $p$-Value \\
\hline AUC $\left(\mathrm{ng} / \mathrm{mL}^{*} \mathrm{~min}\right)$ & $176 \pm 73^{\mathrm{a}}$ & $241 \pm 73^{\mathrm{a}}$ & $439 \pm 73^{\mathrm{b}}$ & 0.02 \\
$\triangle \mathrm{LH}(\mathrm{ng} / \mathrm{mL})$ & $2.4 \pm 0.9^{\mathrm{a}}$ & $3.5 \pm 0.9^{\mathrm{a}}$ & $5.6 \pm 0.9^{\mathrm{b}}$ & $<0.01$ \\
\hline
\end{tabular}

$\overline{\mathrm{a}, \mathrm{b}}$ means within rows without a common superscript differ.

In Groups KP and EBKP, LH remained above pre-treatment levels for 90 min, whereas Group EB12KP continued to have levels of LH above pre-treatment at $270 \mathrm{~min}$ (Figure 2). The greater amplitude of the LH response for Group EB12KP, combined with continued elevated LH, meant that the area under the LH-response curve (AUC) for this group was greater $(p=0.02)$ than for Group KP and Group EBKP, with the latter two groups not differing (Figure 2, Table 1). 


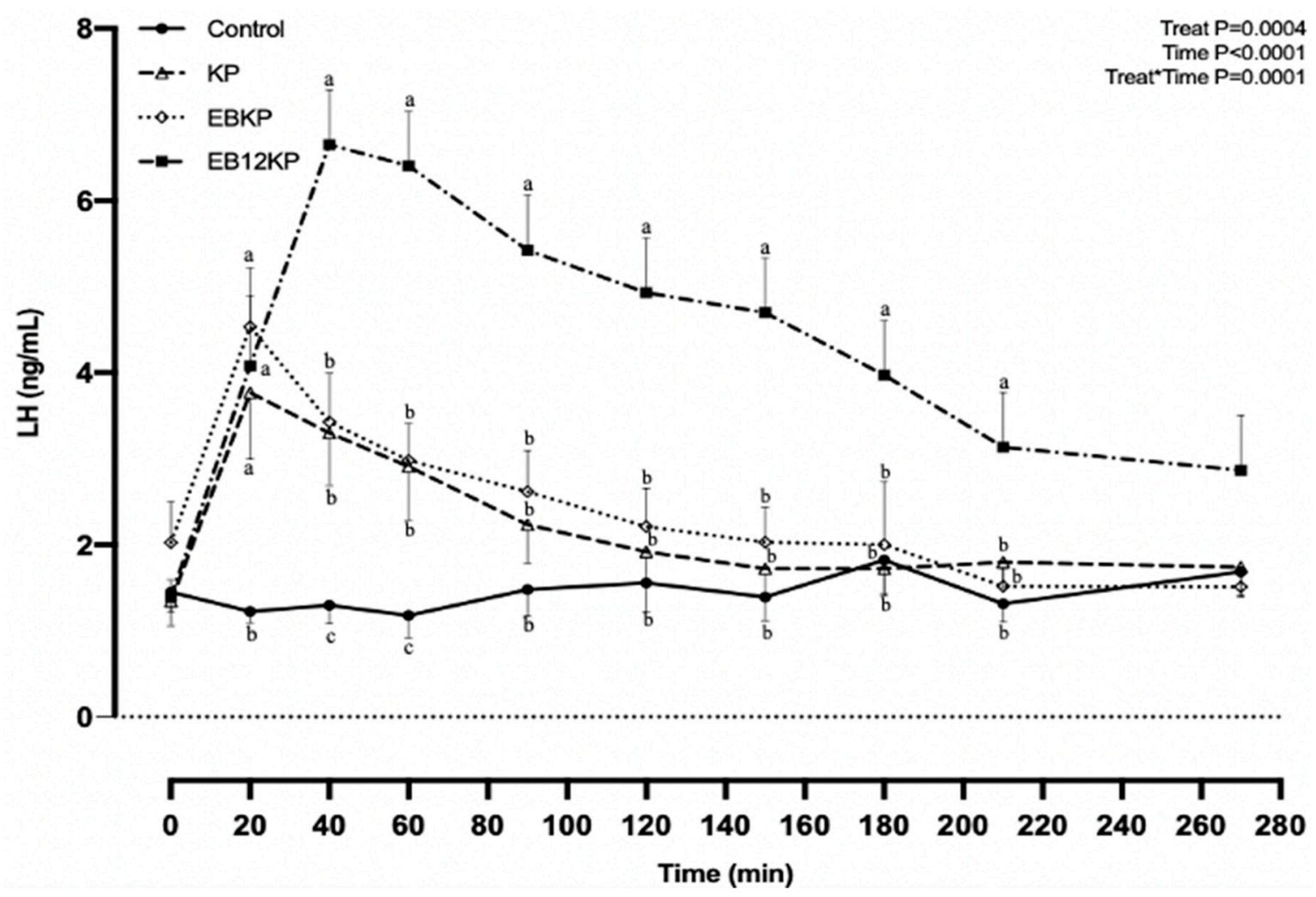

Figure 2. Plasma LH concentrations (means and sem) in ovariectomized Nelore cows $(n=8)$ that received the following treatments: Control, i.m. $4 \mathrm{~mL} \mathrm{0.9 \%} \mathrm{saline} \mathrm{(Control)} \mathrm{at} \mathrm{time} 0$ min; KISS1-10 (KP), i.m. 4 mg murine KISS1-10 in 4 mL $0.9 \%$ saline at time $0 \mathrm{~min}$; EBKP, i.m. $4 \mathrm{mg}$ KISS1-10 + i.m. $2 \mathrm{mg}$ estradiol benzoate (EB) simultaneously at time 0 min; EB12KP, i.m. $2 \mathrm{mg}$ EB $12 \mathrm{~h}$ before i.m. $4 \mathrm{mg}$ KISS1-10 at time 0 min. Treatment, time, and treatment ${ }^{*}$ time effects were highly statistically significant. ${ }^{\mathrm{a}, \mathrm{b}, \mathrm{c}} \mathrm{LH}$ concentrations within time points without a common letter differ $(p<0.05)$.

\section{Discussion}

The hypothesis tested in the present study was that pre-exposure to E2 would have a priming effect and increase the LH response to KISS1 in OVX cows. Cows exposed to EB for $12 \mathrm{~h}$ before treatment with KISS1 showed a greater amplitude in the LH response and longer duration of elevated LH compared with cows treated with EB at the time of KISS1, or cows treated with KISS1 alone. Based on this finding, it was concluded that pre-treatment with EB primed the gonadotrope cells in the anterior pituitary to respond to GnRH. The present study did not include a group treated with EB alone. Whilst this might be considered an omission, the LH response in cows to treatment with EB has been well characterized in previous studies $[6,23]$. The inclusion of an EB group would not have explained the differences in LH response between cows that received EB $12 \mathrm{~h}$ before KISS1 or in conjunction with KISS1. The $12 \mathrm{~h}$ interval between pre-treatment with EB and treatment with KISS1 was based on the report that maximal pituitary GnRH receptors in cows were observed $12 \mathrm{~h}$ after treatment with E2-17 $\beta$ [24]. OVX cows also showed a greater LH response to GnRH when treatment was started $8 \mathrm{~h}$ after an injection of E2-17 $\beta$ compared with $2 \mathrm{~h}$ after an injection of E2-17 $\beta$ [25]. In the present study, KISS1 would have stimulated GnRH neurons in the hypothalamus to release GnRH which then acted at E2-primed gonadotrope cells in the pituitary. A second potential pathway for KISS1induced LH secretion is a direct action of KISS1 at gonadotrope cells. As noted above, gonadotrope cells have GPR54 [17] and KISS1 stimulated LH release by bovine pituitary cells in culture [18]. However, a direct action of KISS1 at gonadotropes in vivo remains controversial and requires further study.

The LH response at $20 \mathrm{~min}$ was similar for cows that received EB either $12 \mathrm{~h}$ before KISS1 or in conjunction with KISS1. This observation could be interpreted to suggest that 
the immediately releasable pool of LH [26] was the same for these two groups of cows and was independent of E2 priming and gonadotrope cell GnRH receptor numbers. The E2 priming response was manifested as a greater amplitude and longer duration of the LH response to KISS1. These two features of LH secretion in E2-primed animals would be expected to increase both the proportion of cows that ovulate and the synchrony of ovulation in cows enrolled in a synchronization-FTAI protocol [20].

GnRH neurons have the KISS1 receptor GPR54 and also neuropeptide Y1 receptor (Y1R) [27] and melanocortin receptor (MCR) [28]. Receptor Y1R is linked to NPY / AgRP (NPY) neurons and receptor MCR is linked to pro-opiomelanocortin (POMC) neurons. NPY and POMC neurons are modulated by nutritional status and metabolic condition and both neurons can either stimulate or suppress GnRH neurons [29,30]. NPY and POMC neurons have $E 2$ receptor- $\alpha(E R \alpha)$ and $E 2-17 \beta$ can inhibit these neurons [31,32]. In the present study, EB administered $12 \mathrm{~h}$ before KISS1 may have suppressed NPY and POMC neurons and reduced their negative action at GnRH neurons. This would have allowed GnRH neurons to undergo a greater response to KISS1. This potential scenario illustrates the complexity of mechanisms and pathways that can influence GnRH-LH secretion. A deeper understanding of this biology could lead to further improvements in synchronization-FTAI protocols.

In previous studies, KISS1 was administered by intravenous (i.v.) or intracerebroventricular (i.c.v.) injection in rodents [33-37], sheep [15,38], primates [36,39], cattle [37] and pigs [40]. A study in calves utilized i.m. KISS1 [13]. The latter study, together with the present findings, showed that i.m. injection of KISS1 induces a release of LH that is comparable to other routes of KISS1 administration. This makes KISS1 practical for potential widespread adoption in synchronization-FTAI protocols. In countries where E2 is not registered for use in cattle, KISS1 agonists with a long half-life in circulation could be a practical option for the induction of LH release in cows [41].

\section{Conclusions}

Priming with E2 for $12 \mathrm{~h}$ increased both the amplitude and the duration of the $\mathrm{LH}$ response after i.m. injection of KISS1 in ovariectomized Nelore cows. The incorporation of E2 priming and KISS1 in estrus synchronization-FTAI protocols could improve the control of LH release and ovulation in cows. This has potential to increase fertilization and conception rates in cows enrolled in estrus synchronization-FTAI programs. There are important implications for assisted breeding and genetic improvement in beef and dairy cattle, and other livestock. Further research is needed to optimize the dose of KISS1 that induces an optimal release of LH for ovulation in cattle.

Author Contributions: Conceptualization, G.G.M. and P.S.B.; methodology, E.d.O.S.B., G.G.M. and G.M.G.d.S.; formal analysis, G.G.M.; writing—original draft preparation, G.G.M. and P.S.B.; writingreview and editing, M.J.D.; project administration, G.G.M. and P.S.B.; funding acquisition, G.G.M. and P.S.B. All authors have read and agreed to the published version of the manuscript.

Funding: This research was funded by the Ourofino Animal Health; and the Brazilian National Council for Scientific and Technological Development (CNPq) [grant number 159829/2011-9].

Institutional Review Board Statement: The study was conducted according to the guidelines of the Declaration of Helsinki, and approved by the Ethics Committee of the University of Sao Paulo, Sao Paulo, Brazil (protocol code 2537, 2012).

Data Availability Statement: Not applicable.

Conflicts of Interest: The authors have read the journal's policy and have the following competing interests: the co-authors (G.M.G.d.S.) are employees of Sheepembryo that partially attended the project. The other authors have no competing interests. 


\section{References}

1. Bó, G.A.; Huguenine, E.; De La Mata, J.J.; Núñez-Olivera, R.; Baruselli, P.S.; Menchaca, A. Programs for fixed-time artificial insemination in South American beef cattle. Anim. Reprod. 2018, 15, 952-962. [CrossRef]

2. Burton, R.J.F.; Farstad, M. Cultural Lock-in and Mitigating Greenhouse Gas Emissions: The Case of Dairy/Beef Farmers in Norway. Sociol. Rural. 2020, 60, 20-39. [CrossRef]

3. Vasconcelos, J.L.M.; Carvalho, R.; Peres, R.F.G.; Rodrigues, A.D.P.; Junior, I.C.; Meneghetti, M.; Aono, F.H.; Costa, W.M.; Lopes, C.N.; Cooke, R.F.; et al. Reproductive programs for beef cattle: Incorporating management and reproductive techniques for better fertility. Anim. Reprod. 2017, 14, 547-557. [CrossRef]

4. $\quad$ Randel, R.D.; Short, R.E.; Christensen, D.S.; Bellows, R.A. Effects of Various Mating Stimuli on the LH Surge and Ovulation Time following Synchronization of Estrus in the Bovine. J. Anim. Sci. 1973, 37, 128-130. [CrossRef] [PubMed]

5. Wiltbank, M.C.; Pursley, J.R. The cow as an induced ovulator: Timed AI after synchronization of ovulation. Theriogenology 2014, 81, 170-185. [CrossRef] [PubMed]

6. Sales, J.N.S.; Carvalho, J.B.P.; Crepaldi, G.A.; Cipriano, R.S.; Jacomini, J.O.; Maio, J.R.G.; Souza, J.C.; Nogueira, G.P.; Baruselli, P.S. Effects of two estradiol esters (benzoate and cypionate) on the induction of synchronized ovulations in Bos indicus cows submitted to a timed artificial insemination protocol. Theriogenology 2012, 78, 510-516. [CrossRef] [PubMed]

7. Garcia-Ispierto, I.; De Rensis, F.; Casas, X.; Caballero, F.; Serrano-Pérez, B.; López-Gatius, F. Inducing ovulation with hCG in a five-day progesterone-based fixed-time AI protocol improves the fertility of anestrous dairy cows under heat stress conditions. Theriogenology 2019, 124, 65-68. [CrossRef]

8. $\quad$ Sá Filho, M.F.; Ayres, H.; Ferreira, R.M.; Marques, M.O.; Reis, E.L.; Silva, R.C.P.; Rodrigues, C.A.; Madureira, E.H.; Bó, G.A.; Baruselli, P.S. Equine chorionic gonadotropin and gonadotropin-releasing hormone enhance fertility in a norgestomet-based, timed artificial insemination protocol in suckled Nelore (Bos indicus) cows. Theriogenology 2010, 73, 651-658. [CrossRef]

9. Bó, G.A.; de la Mata, J.J.; Baruselli, P.S.; Menchaca, A. Alternative programs for synchronizing and resynchronizing ovulation in beef cattle. Theriogenology 2016, 86, 388-396. [CrossRef]

10. Bó, G.A.; Baruselli, P.S. Synchronization of ovulation and fixed-time artificial insemination in beef cattle. Animal 2014, 8, 144-150. [CrossRef]

11. Bisinotto, R.S.; Ribeiro, E.S.; Santos, J.E.P. Synchronisation of ovulation for management of reproduction in dairy cows. Animal 2014, 8, 151-159. [CrossRef]

12. Cardoso Consentini, C.E.; Wiltbank, M.C.; Sartori, R. Factors That Optimize Reproductive Efficiency in Dairy Herds with an Emphasis on Timed Artificial Insemination Programs. Animals 2021, 11, 301. [CrossRef]

13. Macedo, G.G.; Mingoti, R.D.; Batista, E.O.S.; Monteiro, B.M.; Vieira, L.M.; Barletta, R.V.; Wiltbank, M.C.; Nogueira, G.P.; Rennó, F.P.; Maio, J.R.; et al. Profile of LH release in response to intramuscular treatment with kisspeptin in Bos indicus and Bos taurus prepubertal heifers. Theriogenology 2019, 125, 64-70. [CrossRef]

14. Sá Filho, M.F.; Penteado, L.; Siqueira, G.R.; Soares, J.G.; Mendanha, M.F.; Macedo, G.G.; Baruselli, P.S. Timed artificial insemination should be performed early when used norgestomet ear implants are applied for synchronizing ovulation in beef heifers. Theriogenology 2013, 80, 642-647. [CrossRef]

15. Redmond, J.S.; Macedo, G.G.; Velez, I.C.; Caraty, A.; Williams, G.L.; Amstalden, M. Kisspeptin activates the hypothalamicadenohypophyseal-gonadal axis in prepubertal ewe lambs. Reproduction 2011, 141, 541-548. [CrossRef] [PubMed]

16. Smith, J.T.; Rao, A.; Pereira, A.; Caraty, A.; Millar, R.P.; Clarke, I.J. Kisspeptin Is Present in Ovine Hypophysial Portal Blood But Does Not Increase during the Preovulatory Luteinizing Hormone Surge: Evidence that Gonadotropes Are Not Direct Targets of Kisspeptin in Vivo. Endocrinology 2008, 149, 1951-1959. [CrossRef] [PubMed]

17. Gutiérrez-Pascual, E.; Martínez-Fuentes, A.J.; Pinilla, L.; Tena-Sempere, M.; Malagón, M.M.; Castaño, J.P. Direct Pituitary Effects of Kisspeptin: Activation of Gonadotrophs and Somatotrophs and Stimulation of Luteinising Hormone and Growth Hormone Secretion. J. Neuroendocrinol. 2007, 19, 521-530. [CrossRef] [PubMed]

18. Suzuki, S.; Kadokawa, H.; Hashizume, T. Direct kisspeptin-10 stimulation on luteinizing hormone secretion from bovine and porcine anterior pituitary cells. Anim. Reprod. Sci. 2008, 103, 360-365. [CrossRef]

19. Gahete, M.D.; Vázquez-Borrego, M.C.; Martínez-Fuentes, A.J.; Tena-Sempere, M.; Castaño, J.P.; Luque, R.M. Role of the Kiss1/Kiss1r system in the regulation of pituitary cell function. Mol. Cell. Endocrinol. 2016, 438, 100-106. [CrossRef]

20. Souza, A.H.; Cunha, A.P.; Silva, E.P.B.; Gümen, A.; Ayres, H.; Guenther, J.N.; Wiltbank, M.C. Comparison of gonadorelin products in lactating dairy cows: Efficacy based on induction of ovulation of an accessory follicle and circulating luteinizing hormone profiles. Theriogenology 2009, 72, 271-279. [CrossRef] [PubMed]

21. Skarda, R.T. Local and Regional Anesthesia in Ruminants and Swine. Vet. Clin. N. Am. Food Anim. Pract. 1996, 12, 579-626. [CrossRef]

22. Bolt, D.J.; Scott, V.; Kiracofe, G.H. Plasma LH and FSH after estradiol, norgestomet and Gn-RH treatment in ovariectomized beef heifers. Anim. Reprod. Sci. 1990, 23, 263-271. [CrossRef]

23. Martínez, M.F.; Kastelic, J.P.; Colazo, M.G.; Mapletoft, R.J. Effects of estradiol on gonadotrophin release, estrus and ovulation in CIDR-treated beef cattle. Domest. Anim. Endocrinol. 2007, 33, 77-90. [CrossRef]

24. Schoenemann, H.M.; Humphrey, W.D.; Crowder, M.E.; Nett, T.M.; Reeves, J.J. Pituitary Luteinizing Hormone-releasing Hormone Receptors in Ovariectomized Cows after Challenge with Ovarian Steroids. Biol. Reprod. 1985, 32, 574-583. [CrossRef] 
25. Kesner, J.S.; Convey, E.M.; Anderson, C.R. Evidence that Estradiol Induces the Preovulatory LH Surge in Cattle by Increasing Pituitary Sensitivity to LHRH and then Increasing LHRH Release. Endocrinology 1981, 108, 1386-1391. [CrossRef]

26. Clarke, I.J.; Cummins, J.T. GnRH pulse frequency determines LH pulse amplitude by altering the amount of releasable LH in the pituitary glands of ewes. J. Reprod. Fertil. 1985, 73, 425-431. [CrossRef]

27. Klenke, U.; Constantin, S.; Wray, S. Neuropeptide Y Directly Inhibits Neuronal Activity in a Subpopulation of GonadotropinReleasing Hormone-1 Neurons via Y1 Receptors. Endocrinology 2010, 151, 2736-2746. [CrossRef]

28. Ericson, M.D.; Lensing, C.J.; Fleming, K.A.; Schlasner, K.N.; Doering, S.R.; Haskell-Luevano, C. Bench-top to clinical therapies: A review of melanocortin ligands from 1954 to 2016. Biochim. Biophys. Acta Mol. Basis Dis. 2017, 1863, 2414-2435. [CrossRef]

29. Advis, J.P.; Klein, J.; Kuljis, R.O.; Sarkar, D.K.; McDonald, J.M.; Conover, C.A. Regulation of Gonadotropin Releasing Hormone Release by Neuropeptide Y at the Median Eminence during the Preovulatory Period in Ewes. Neuroendocrinology 2003, 77, 246-257. [CrossRef]

30. Roa, J.; Herbison, A.E. Direct Regulation of GnRH Neuron Excitability by Arcuate Nucleus POMC and NPY Neuron Neuropeptides in Female Mice. Endocrinology 2012, 153, 5587-5599. [CrossRef]

31. Bauer-Dantoin, A.C.; Urban, J.H.; Levine, J.E. Neuropeptide Y gene expression in the arcuate nucleus is increased during preovulatory luteinizing hormone surges. Endocrinology 1992, 131, 2953-2958. [CrossRef] [PubMed]

32. Xu, Y.; Nedungadi, T.P.; Zhu, L.; Sobhani, N.; Irani, B.G.; Davis, K.E.; Zhang, X.; Zou, F.; Gent, L.M.; Hahner, L.D.; et al. Distinct Hypothalamic Neurons Mediate Estrogenic Effects on Energy Homeostasis and Reproduction. Cell Metab. 2011, 14, 453-465. [CrossRef] [PubMed]

33. Irwig, M.S.; Fraley, G.S.; Smith, J.T.; Acohido, B.V.; Popa, S.M.; Cunningham, M.J.; Gottsch, M.L.; Clifton, D.K.; Steiner, R.A. Kisspeptin Activation of Gonadotropin Releasing Hormone Neurons and Regulation of KiSS-1 mRNA in the Male Rat. Neuroendocrinology 2004, 80, 264-272. [CrossRef]

34. Gottsch, M.L.; Cunningham, M.J.; Smith, J.T.; Popa, S.M.; Acohido, B.V.; Crowley, W.F.; Seminara, S.; Clifton, D.K.; Steiner, R.A. A Role for Kisspeptins in the Regulation of Gonadotropin Secretion in the Mouse. Endocrinology 2004, 145, 4073-4077. [CrossRef] [PubMed]

35. Navarro, V.M.; Castellano, J.M.; Fernndez-Fernndez, R.; Barreiro, M.L.; Roa, J.; Sanchez-Criado, J.E.; Aguilar, E.; Dieguez, C.; Pinilla, L.; Tena-Sempere, M. Developmental and Hormonally Regulated Messenger Ribonucleic Acid Expression of KiSS-1 and Its Putative Receptor, GPR54, in Rat Hypothalamus and Potent Luteinizing Hormone-Releasing Activity of KiSS-1 Peptide. Endocrinology 2004, 145, 4565-4574. [CrossRef] [PubMed]

36. Dhillo, W.S.; Chaudhri, O.B.; Patterson, M.; Thompson, E.L.; Murphy, K.G.; Badman, M.K.; McGowan, B.M.; Amber, V.; Patel, S.; Ghatei, M.A.; et al. Kisspeptin-54 Stimulates the Hypothalamic-Pituitary Gonadal Axis in Human Males. J. Clin. Endocrinol. Metab. 2005, 90, 6609-6615. [CrossRef]

37. Kadokawa, H.; Matsui, M.; Hayashi, K.; Matsunaga, N.; Kawashima, C.; Shimizu, T.; Kida, K.; Miyamoto, A. Peripheral administration of kisspeptin-10 increases plasma concentrations of GH as well as LH in prepubertal Holstein heifers. J. Endocrinol. 2008, 196, 331-334. [CrossRef] [PubMed]

38. Messager, S.; Chatzidaki, E.E.; Ma, D.; Hendrick, A.G.; Zahn, D.; Dixon, J.; Thresher, R.R.; Malinge, I.; Lomet, D.; Carlton, M.B.L.; et al. Kisspeptin directly stimulates gonadotropin-releasing hormone release via G protein-coupled receptor 54. Proc. Natl. Acad. Sci. USA 2005, 102, 1761-1766. [CrossRef]

39. Shahab, M.; Mastronardi, C.; Seminara, S.B.; Crowley, W.F.; Ojeda, S.R.; Plant, T.M. Increased hypothalamic GPR54 signaling: A potential mechanism for initiation of puberty in primates. Proc. Natl. Acad. Sci. USA 2005, 102, 2129-2134. [CrossRef]

40. Lents, C.A.; Heidorn, N.L.; Barb, C.R.; Ford, J.J. Central and peripheral administration of kisspeptin activates gonadotropin but not somatotropin secretion in prepubertal gilts. Reproduction 2008, 135, 879-887. [CrossRef]

41. Decourt, C.; Robert, V.; Lomet, D.; Anger, K.; Georgelin, M.; Poissenot, K.; Pellicer-Rubio, M.-T.; Aucagne, V.; Beltramo, M. The kisspeptin analog C6 is a possible alternative to PMSG (pregnant mare serum gonadotropin) for triggering synchronized and fertile ovulations in the Alpine goat. PLoS ONE 2019, 14, e0214424. [CrossRef] [PubMed] 